\title{
Pengaruh Komposisi Pakan Terhadap Laju Pertumbuhan Tukik Penyu Lekang di Serangan, Bali
}

\author{
Feny Amelia Ginting*, Ali Djunaedi, Raden Ario \\ Departemen IImu Kelautan, Fakultas Perikanan dan IImu Kelautan, Universitas Diponegoro \\ Jl. Prof. H. Soedarto S.H, Tembalang Semarang, Jawa Tengah 50275 Indonesia \\ *Corresponding author, e-mail: fenyameliaginting98@gmail.com
}

\begin{abstract}
ABSTRAK: Tingkat keberhasilan hidup tukik menuju dewasa dapat ditentukan dengan pemberian pakan. Tetapi, saat ini jenis pakan yang paling tepat untuk tukik penyu belum diketahui. Pemberian jenis pakan dengan komposisi dan dosis yang tepat akan mempengaruhi tingkat pertumbuhan tukik penyu lekang dengan baik dan akan mempengaruhi keberhasilan hidupnya saat dilepaskan ke laut. Tujuan dari penelitian ini adalah mengetahui pengaruh pemberian pakan dengan komposisi yang berbeda terhadap pertumbuhan tukik Penyu Lekang (Lepidochelys olivacea) dan mengetahui tingkat kelulusan hidupnya selama masa pemeliharaan 5 Minggu. Lokasi penelitian dilakukan di Turtle Conservation and Education Center Serangan, Bali. Metode penelitian yang digunakan adalah metode eksperimental dengan menggunakan Rancangan Acak Lengkap (RAL) dengan 4 perlakuan yaitu ikan tongkol $100 \%(A)$,ikan tongkol $75 \%$ : kerang totok $25 \%(B)$, ikan tongkol $50 \%$ : kerang totok $50 \%$ (C), ikan tongkol 25\% : kerang totok $75 \%$ dan masing- masing 3 ulangan disetiap perlakuan. Tukik Penyu Lekang diberikan pakan setiap pagi dan sore, dan diukur pertambahan berat, panjang, lebar dan morfologinya setiap 1 minggu sekali. hasil penelitian dapat disimpulkan bahwa pemberian pakan Ikan Tongkol dengan perbandingan komposisi yang berbeda memberikan pengaruh yang sangat nyata $(p<0,05)$ terhadap laju pertumbuhan spesifik berat, panjang karapas, dan lebar karapas tukik Penyu Lekang. Pakan dengan komposisi lkan Tongkol $100 \%$ merupakan pakan paling baik diantara perlakuan pakan lainnya, dengan menghasilkan tingkat laju pertumbuhan spesifik berat $1,43 \%$ perhari, panjang karapas $0,62 \%$ perhari dan lebar karapas $0,94 \%$ perhari.
\end{abstract}

Kata kunci: Lepidochelys olivacea, pakan, pertumbuhan

\section{The Effect of Feed Composition on the Growth Rate of Olive Ridley Hatchlings in Serangan, Bali}

ABSTRACT: The success rate of living for hatchlings to adulthood can be determined by feeding. However, it is currently unknown what type of feed is most suitable for turtle hatchlings. The provision of types of feed with the right composition and dosage will affect the growth rate of the lekang turtle hatchlings and will affect their success when released into the sea. The purpose of this study was to determine the effect of feeding with different compositions on the growth of Olive Ridley (Lepidochelys olivacea) hatchlings and to determine their survival rate during the 5 week rearing period. The research location was conducted at the Turtle Conservation and Education Center Serangan, Bali. The research method used was an experimental method using a completely randomized design (CRD) with 4 treatments, namely 100\% tuna $(A), 75 \%$ tuna: $25 \%$ totok $(B), 50 \%$ tuna: $50 \%$ totok (C), tuna $25 \%$ : $75 \%$ totok clams and 3 replications each in each treatment. Lekang Turtle Hatchlings are given food every morning and evening, and their weight, length, width and morphology gain is measured every 1 week. The results showed that feeding Tuna Fish with different composition ratios had a very significant effect $(p<0.05)$ on the specific growth rate of weight, carapace length, and carapace width of the Lekang turtle hatchlings. Feed with $100 \%$ tuna composition is the best feed among other feed treatments, with a specific weight growth rate of $1.43 \%$ per day, carapace length $0.62 \%$ per day and carapace width $0.94 \%$ per day.

Keywords: Lepidochelys olivacea, feed, growth 


\section{PENDAHULUAN}

Penyu merupakan hewan reptil yang menghabiskan masa hidupnya dilaut dan keberadaan populasinya semakin berkurang hingga saat ini (Mansula dan Agus, 2020). Semua jenis penyu termasuk dalam kategori threatened species dan dimasukan dalam daftar merah IUCN (International Union for Conservation of Nature and Natural Resources) yang berarti terancam punah dan dilindungi. Berkurangnya populasi penyu saat ini paling banyak disebabkan oleh ulah manusia seperti pengambilan telur penyu secara liar, mengkonsumsi daging penyu dan kawasan pantai untuk bertelur yang banyak dijadikan tercemar dan rusak yang membuat penyu merasa terganggu (Manurung et al., 2015). Berdasarkan hal ini dibutuhkan inovasi ataupun program dalam meningkatkan populasi penyu agar tidak punah. Salah satu cara yang dapat dilakukan adalah dengan melakukan pemeliharaan dari masa tukik penyu hingga dia akan di lepaskan ke laut (Dewi et al., 2018). Inovasi yang dilakukan ini diharapkan dapat bertambahnya populasi penyu.

Pemeliharaan tukik ini biasanya dilakukan di tempat konservasi penyu salah satunya adalah TCEC (Turtle Conservation and Education Center) Serangan, Bali. Program yang dilakukan di oleh pihak TCEC Serangan yaitu meliputi penetasan semi alami telur penyu, pemeliharaan bayi penyu, dan perawatan penyu yang sakit. Terkadang di tempat konservasi ini juga mendapat telor penyu dari masyarakat yang tak sengaja menemukan telur penyu di pantai. Pemeliharaan tukik penyu yang berada di TCEC lebih banyak jenis tukik Penyu Lekang (Lepidochelys olivacea) tetapi juga terdapat jenis Penyu Hijau (Chelonia mydas) dan Penyu Sisik (Eretmochelys imbricate) (Ario et al., 2016).

Pemeliharaan tukik Penyu Lekang membutuhkan pakan untuk menunjang pertumbuhannya agar saat dilepaskan ke laut dia memiliki daya tahan yang lebih kuat. Ketersediaan maupun harga satuan bahan pakan menjadi salah satu faktor yang paling penting dalam memperoleh suatu pakan. Hal ini bertujuan agar tidak mengalami kesulitan karena keterbatasan produksi pakannya. Perubahan pemberian pakan dalam suatu siklus produktif dapat mempengaruhi petumbuhan tukik, hal ini disebabkan karena tukik yang sudah terbiasa dengan pakan produksi tertentu dapat mengalami stress jika pakan yang diberikan berubah. Hal inilah yang menyebabkan ketersediaan pakan menjadi salah satu yang penting dilakukan. Oleh karena itu, penelitian mengenai pemberian pakan yang berbeda terhadap pertumbuhan tukik Penyu Lekang ini perlu dilakukan untuk memberikan informasi kepada para pekerja di penangkaran sebagai pakan alternatif.

Penelitian tentang pemberian pakan untuk mempercepat pertumbuhan tukik penyu sebelumnya sudah pernah dilakukan oleh Hardiono et al. (2012) dengan pemberian pakan udang ebi kepada tukik Penyu Lekang (Lepidochelys olivacea) di Pantai Samas, Bantu dan penelitian yang dilakukan oleh Suraeda et al. (2018) dengan pemberian pakan buatan kepada tukik Penyu Lekang (Lepidochelys olivacea) di Turtle Conservation And Education Center. Pemberian pakan pada tukik setidaknya harus menggunakan pakan yang sama seperti pada habitat aslinya di alam yaitu berupa pakan segar agar saat di lepaskan ke laut tukik tidak merasa terlalu sulit untuk beradaptasi dengan tekstur makanan yang dia makan di laut dengan yang dia makan di tempat penangkaran yang sebelumnya dan penggunaan pakan mudah yang mudah di dapatkan di wilayah penangkaran tersebut. Penelitian ini bertujuan yaitu untuk mengetahui laju pertumbuhan berat, panjang karapas dan lebar karapas dengan pemberian pakan yang memiliki berbedaan komposisi pada tukik Penyu Lekang (Lepidochelys olivacea) di TCEC Serangan, Bali. Budidaya penyu dengan inovasi seperti ini diharapkan berdampak terhadap penambahan jumlah penyu yang dapat hidup hingga dewasa sehingga penyu masih ada ini dapat dinikmati oleh semua orang (Firdaus et al ., 2013).

\section{MATERI DAN METODE}

Penelitian dilakukan selama 5 minggu mulai dari tanggal 30 November 2019 hingga 6 Januari 2020 yang dilakukan di Turtle Conservation And Education Center (TCEC) Serangan, Bali. Materi yang digunakan adalah 24 ekor tukik penyu lekang (Lepidochelys olivacea) yang didapatkan dari hasil penetas di Turtle Conservation and Education Center (TCEC) Serangan, Bali dan pakan yang dikonsumsi selama penelitian yaitu perlakuan A (Ikan Tongkol $100 \%$ ), perlakuan (Komposisi Ikan Tongkol 75\%: Kerang Totok 25\%), C (Komposisi Ikan Tongkol 50\%: Kerang Totok 50\%), D (Komposisi Ikan Tongkol 25\%: Kerang Totok 75\%). Sampel pakan di uji di Laboratorium Nutrisi dan Makanan Ternak, Fakultas Peternakan, Universitas Udayana, Bali. Parameter yang diamati yaitu pertumbuhan 
berat, panjang karapas dan lebar karapas yang diukur setiap sekali seminggu yaitu selama 5 minggu.

Data pendukung dalam penelitian ini adalah data ukuran morfologi tukik Penyu Lekang yang dilakukan selama seminggu sekali, pengukuran suhu menggunakan thermometer, pengukuran salinitas menggunakan refraktometer dan pengukuran $\mathrm{pH}$ menggunakan $\mathrm{pH}$ meter. Hal itu dilakukan untuk mengetahui kualitas air pada tukik agar kehidupan tukik tetap terjaga. Pengukuran suhu, pH dan salinitas dilakukan pada pukul 09.00 WITA setelah melakukan pergantian air.

Metode yang digunakan adalah metode percobaan eksperimen dan rancangan yang digunakan dalam penelitian ini adalah rancangan acak lengkap (RAL), menggunakan 4 perlakuan dan 3 kali pengulangan. Selain mengamati laju pertumbuhan dan parameter pendukung tersebut, pada peneliatin ini juga akan mengamati Rasio Konversi Pakan (FCR).

Perhitungan laju pertumbuhan spesifik/ Spesific Growth Rate (SGR) dihitung dengan menggunakan rumus dari Lazaren et al. (2014). Kemampuan tukik untuk memakan atau Feed Conversion Ratio (FCR) dan perhitungan morfologi dihitung menggukanan rumus dari Nuansa et al. (2018). Analisis yang digunakan pada pengolahan data kali ini adalah anlisis of varian (ANOVA) yang menguji perbedaan dari hasil pertambahan perubahan pertumbuhan karena pemberian pakan. Menurut Menurut Lazaren et al. (2018), analisis varian adalah pengujian perbedaan dari hasil penelitian (pertambahan perubah pertumbuhan) karena pengaruh perlakuan pemberian pakan Ada beberapa asumsi yang harus dipenuhi agar dapat menggunakan uji ANOVA yaitu uji normalitas dan uji homogenitas.

Analisa proksimat pada penelitian ini digunakan untuk mengetahui kandungan nutrisi yang terkandung di masing-masing komposisi pakan yang diberikan kepada tukik Penyu Lekang. Analisis proksimat dilakukan dalam beberapa langkah pengujian untuk setiap komposisinya di Laboratorium Nutrisi dan Makanan Ternak Fakultas Peternakan - Universitas Udayana.

\section{HASIL DAN PEMBAHASAN}

Berdasarkan dari penelitian yang telah dilakukan selama 5 minggu, hasil penelitian menunjukkan adanya nilai selisih terhadap pertumbuhan spesifik (SGR) pada tukik penyu lekang hal ini dapat dilihat pada gambar 1 dimana laju spesifik pertumbuhan pada setiap perlakuan menunjukkan terjadinya selisih pada pertambahan berat tukik Penyu Lekang selama masa penelitian. Selisih berat yang dihasilkan pada perlakuan A memiliki selisih rata - rata 2,47 $\mathrm{g}$, perlakuan B 1,74 g, perlakuan C 1,17 g dan perlakuan D 0,85 g. Selisih pada pertambahan panjang tukik Penyu Lekang selama masa penelitian dimana pada perlakuan A memiliki selisih rata-rata 0,30 $\mathrm{cm}$, perlakuan $B 0,14 \mathrm{~cm}$, perlakuan $C 0,11 \mathrm{~cm}$ dan perlakuan $D 0,77 \mathrm{~cm}$. Selisih pada pertambahan lebar karapas tukik Penyu Lekang selama masa penelitian dimana pada perlakuan A memiliki selisih rata-rata $0,29 \mathrm{~cm}$, perlakuan $B \quad 0,17 \mathrm{~cm}$, perlakuan $C 0,11 \mathrm{~cm}$ dan perlakuan $D 0,85 \mathrm{~cm}$.

Hasil laju pertumbuhan spesifik berat, panjang karapas dan lebar karapas pada setiap perlakuan mencapai rata-rata laju pertumbuhan spesifik tertinggi dan terendah serta menunjukkan nilai standar deviasi dari laju pertumbuhan spesifik Penyu Lekang. Laju pertumbuhan spesifik berat pada Perlakuan A memiliki rata-rata dan standar deviasi pertumbuhan spesifik yang paling tinggi yaitu $1,43 \pm 0,14 \%$ perhari dan yang terendah adalah perlakuan $D$ dengan hasil $0,60 \pm 0,08 \%$ perhari. Hasil laju pertumbuhan spesifik panjang karapas tukik Penyu Lekang pada perlakuan A memiliki rata-rata pertumbuhan spesifik yang tertinggi $0,62 \pm 0,03 \% /$ hari dan yang terendah adalah perlakuan D yaitu $0,13 \pm 0,015 \% /$ hari dan hasil laju pertumbuhan spesifik lebar karapas tukik Penyu Lekang pada perlakuan A memiliki rata-rata dan standar deviasi pertumbuhan spesifik tertinggi $0,94 \pm 0,04 \% /$ hari dan yang terendah adalah perlakuan $D$ yaitu $0,28 \pm 0,05 \% /$ hari.

Hasil penelitian menunjukkan bahwa pemberian perlakuan pakan menghasilkan perbedaan pertumbuhan. Hal tersebut diduga diakibatkan oleh kandungan nutrisi yang ada di masing-masing pakan. Hal ini sesuai dengan pendapat Sulawesty et al. (2014), bahwa kombinasi pakan yang tepat akan mendukung pertumbuhan, pencegahan infeksi dan meningkatkan tingkat kelangsungan hidup. Hanipa et al. (2017), bahwa pertumbuhan penyu dapat diketahui melalui pengamatan yang pada umumnya dilakukan berdasarkan pertambahan berat dan karapasnya.

Hasil laju pertumbuhan spesifik berat, panjang karapas dan lebar karapas tukik Penyu Lekang juga menunjukkan hasil tertinggi dicapai oleh pakan $A$ dan yang terendah adalah perlakuan $D$ (Gambar 1). Berdasarkan hasil perhitungan statistik anova pemberian pakan berbeda memberikan 
pengaruh nyata terhadap pertumbuhan tukik Penyu Lekang dan pada hasil uji lanjut yang di lakukan pemberian pakan menggunakan komposisi yang berbeda memiliki hasil yang berbeda jika dilihat dari perbandingan dari satu perlakuan ke perlakuan yang lain.

Hal ini juga diduga karena pada pakan A dengan komposisi lkan Tongkol 100\% memiliki kandungan gizi yang lebih besar jika dibandingkan dengan pakan yang lain seperti yang ada pada hasil uji proksimat (Tabel 1) didapatkan kandungan protein pada pakan tongkol $100 \%$ ini sebesar $37,04 \%$. Temuan ini menguatkan pendapat Hardiono et al. (2012) yang mengatakan bahwa pertumbuhan semakin cepat apabila pakan mengandung protein yang tinggi, dimana kandungan protein yang tinggi pada pakan campuran ini menjadi penyebab tingginya laju pertumbuhan tukik. Protein memiliki fungsi sebagai komponen utama dalam pembentukkan sel atau jaringan pada masa pertumbuhan, sehingga apabila nutrisi protein tersebut tercukupi maka pertumbuhan yang dihasilkan juga dapat berjalan lebih cepat. Menurut Gusniati et al. (2013) protein dan kalsium termasuk dalam kandungan gizi yang dapat meningkatkan pertumbuhan (bobot maupun panjang karapas pada tukik).

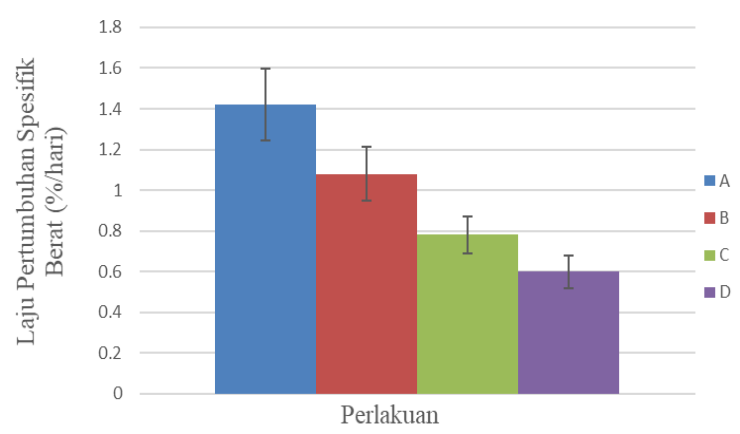

(a)

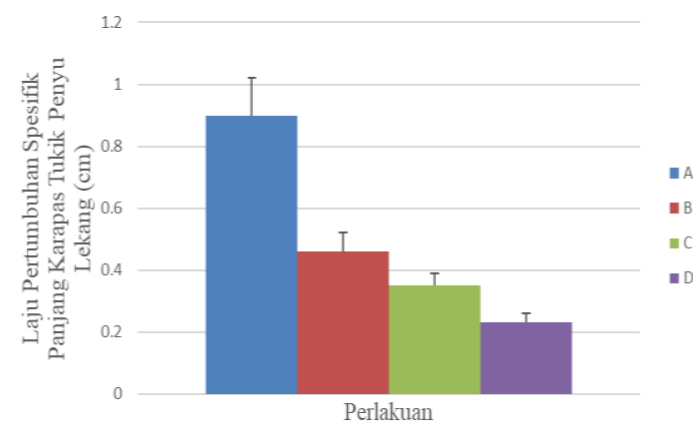

(b)

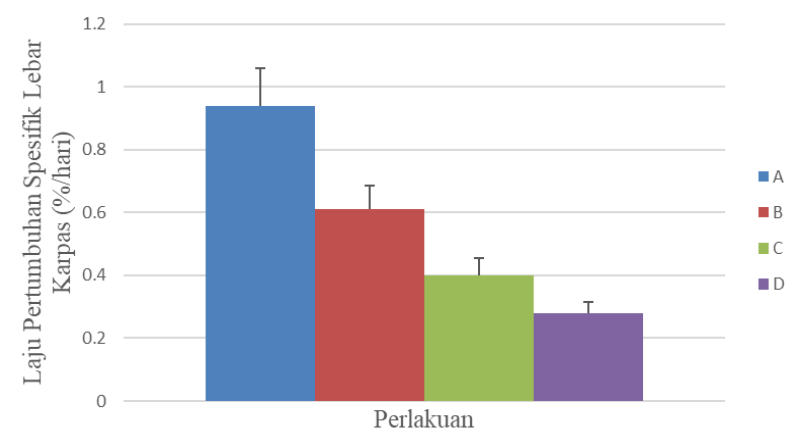

(c)

Gambar 1. Laju Pertumbuhan Spesifik (a) Berat (b) Panjang Karapas (c) Lebar Karapas(\%/Hari) Tukik Penyu Lekang Selama Penelitian dengan Pakan

Tabel 1. Hasil Uji Proksimat

\begin{tabular}{|c|c|c|c|c|c|c|c|}
\hline \multirow{2}{*}{ Pakan } & \multirow{2}{*}{ Komposisi } & \multicolumn{6}{|c|}{ Kadar dalam \% Berat Kering } \\
\hline & & Air & Abu & Protein & Serat & Lemak & Karbohidrat \\
\hline A & Tongkol (100\%) & 50,11 & 2,25 & 37,03 & 0,26 & 10,54 & 0,01 \\
\hline B & Tongkol (75\%)+ Kerang (25\%) & 50,85 & 2,44 & 34,44 & 0,29 & 10,80 & 2,88 \\
\hline $\mathrm{C}$ & Tongkol (50\%)+ Kerang (50\%) & 51,02 & 3,18 & 28,66 & 0,31 & 11,07 & 7,81 \\
\hline $\mathrm{D}$ & Tongkol (25\%)+ Kerang (75\%) & 51,29 & 5,51 & 28,03 & 0,35 & 12,04 & 5,36 \\
\hline
\end{tabular}


Dengan adanya kombinasi kandungan gizi terutama protein pada pakan ini terlihat bahwa pertumbuhan berat, panjang karapas dan lebar karapas pada tukik memiliki rata-rata tertinggi pada perlakuan A. Selain protein kandungan karbohidrat, lemak dan mineral juga menjadi indikator terhadap laju pertumbuhan tukik. Hal ini di dukung oleh pernyataan Marzuqi dan Anjusary (2013), bahwa kandungan gizi berupa karbohidrat, protein dan lemak pada pakan dapat mempengaruhi tinggi rendahnya pertumbuhan pada biota. Semakin baik kualitas pakan yang digunakan maka semakin tinggi pula kandungan gizi yang terdapat pada pakan tersebut. Pakan yang dinyatakan memiliki kualitas yang baik dan bermutu jika memberikan pengaruh yang positif terhadap pertumbuhan tukik.

Berdasarkan hasil didapatkan juga menunjukkan bahwa pada perlakuan pakan D (Ikan Tongkol 25\%: Kerang Totok $75 \%$ ) memiliki laju pertumbuhan yang paling kecil jika dibandingkan dengan yang lain, namun memiliki kandungan kadar serat yang lebih tinggi dari pakan yang lain (Gambar 1). Rendahnya laju pertumbuhan tukik pada perlakuan D ini di duga terjadi karena tukik sulit mencerna pakan dari Kerang Totok yang memiliki kandungan serat yang tinggi, hal ini di perkuat oleh pernyataan Lazaren et al. (2018), bahwa pakan yang mengandung serat yang tinggi akan sulit dicerna. Hal ini juga akan menyebabkan tukik Penyu Lekang lebih cepat merasa kenyang. Menurut Dewi et al. (2018), hal ini juga dapat terjadi karena nutrisi yang ada pada pakan belum seimbang karena asam amino yang ada pada lemak dengan protein belum sesuai maka pada tukik sehingga menghasilkan rata - rata pertumbuhan berat dan panjang yang kecil. Apabila protein yang diserap dan dicerna dalam bentuk asam amino seimbang maka hasilnya akan terpresentasikan menjadi organ pada masa pertumbuhan tukik Penyu Lekang dan akan mempengaruhi pertumbuhannya. Asam amino yang terkandung didalam makanan juga berfungsi menjaga kesehataan tubuh (Putra, 2015).

Sebagai pembanding, pada penelitian sebelumnya dengan penggunaan pakan dari cacahan daging ikan layang, udang vannamei dan kerang kepah (Wiguna et al., 2019). Berbedanya jenis pakan yang diberikan pada masing-masing perlakuan memberikan hasil pertumbuhan yang berbeda pada setiap perlakuan. Pertumbuhan yang terjadi pada tukik Penyu Lekang berpengaruh terhadap pembentukan sel dan jaringan pada setiap masa pertumbuhannya. Pertumbuhan dapat diartikan sebagai penambahan bobot dan ukuran berupa peningkatan jumlah sel maupun ukuran suatu organisme yang diukur pada satuan waktu tertentu (Hanipa et al., 2017). Menurut Effendie (1997) pakan yang dikonsumsi akan menjadi energi dan pertama-tama akan digunakan untuk memelihara tubuh dan mengganti sel-sel yang rusak, selebihnya digunakan untuk pertumbuhan.

Perbedaan laju pertumbuhan antar perlakuan dapat diketahui dengan melakukan analisis ANOVA. Dalam analisis ANOVA ini menggunakan analisis parametrik dan non parametrik yaitu uji Kruskal Wallis Imenggunakan 2 hipotesis $\mathrm{H}_{0}$ dan $\mathrm{H}_{1}, \mathrm{H}_{0}$ menyatakan tidak terdapat perbedaan rerata dan $\mathrm{H}_{1}$ menyatakan terdapat perbedaan rerata. Sedangkan dasar keputusan uji Kruskal Wallis adalah jika nilai Asymp Sig. > 0,05 maka tidak ada perbedaan atau $\mathrm{H}_{0}$ diterima, dan $\mathrm{H}_{1}$ ditolak. Jika nilai Asymp Sig. < 0,05 maka ada perbedaan atau $\mathrm{H}_{1}$ diterima dan $\mathrm{H}_{0}$ ditolak (Siegel, 1988). Berdasarkan hasil penelitian dapat disimpulkan bahwa pemberian pakan Ikan Tongkol dengan perbandingan komposisi yang berbeda memberikan pengaruh yang sangat nyata $(p<0,05)$ ataupun adanya pengaruh dari perlakuan perbedaan jenis pakan terhadap laju pertumbuhan tukik (memiliki ratarata laju pertumbuhan yang bernilai tidak sama / berbeda)dengan selang kepercayaan 95 \%.terhadap laju pertumbuhan spesifik berat, panjang karapas, dan lebar karapas tukik Penyu Lekang.

Hasil rasio konversi pakan A menunjukan nilai terkecil dibandingkan nilai yang lain yaitu 4,28 $\pm 0,38$ sedangkan pakan B memiliki nilai rasio konversi pakan mencapai $5,7 \pm 0,42$; pakan $\mathrm{C}$ memiliki nilai rasio konversi pakan mencapai 7,98 $\pm 1,91$ dan pakan $D$ memiliki nilai konversi pakan mencapai $10,02 \pm 1,25$. Pada perlakuan pakan A merupakan komposisi pakan yang terbaik karena memiliki nilai FCR yang paling rendah, hal ini diperkuat oleh pernyataan Sulawesty et al. (2014), yang menyatakan bahwa rasio konversi pakan menunjukkan keefisienan dalam pemberian pakan dimana nilai yang makin rendah menunjukkan bahwa makanan yang dapat dimanfaatkan dalam tubuh lebih baik dan kualitas makanannya lebih baik juga, karena dengan pemberian sejumlah pakan yang sama akan memberikan pertambahan berat tubuh yang lebih tinggi. Rendahnya nilai FCR di duga karena nutrisi pada pakan yang diberikan kepada tukik Penyu Lekang sesuai dengan kebutuhannya. Nilai pada rasio konversi pakan berhubungan dengan kualitas pakan yang digunakan, sehingga 
semakin rendah nilai yang didapatkan maka semaikin baik pula kualitas pakan yang digunakan. Pada hasil tersebut dapat dilihat efisiensi pemanfaatan pakan yang sesuai dengan nilai rasio konversi pakan, maka paling sesuai dari ke empat uji tersebut dengan nilai rasio pakan (FCR) tukik Penyu Lekang adalah pakan A (Pakan Ikan Tongkol 100\%) yang masih layak diberikan sebagai pakan guna menunjang laju pertumbuhan tukik Penyu Lekang.

Kualitas air yang digunakan untuk media hidup tukik yang dipeliharaan di bak pememliharaan memerlukan perhatian khusus. Pengamatan terhadap kualitas air dilakukan karena merupakan salah satu faktor lingkungan yang mempengaruhi pertumbuhan tukik penyu lekang dalam penelitian. Pengukuran parameter kualitas air ini juga untuk mengetahui kondisi lingkungan terhadap laju pertumbuhan tukik Penyu Lekang. Parameter yang harus diperhatikan dalam menjaga kualitas air media antara lain $\mathrm{pH}$, salinitas dan suhu.

Hasil kualitas air di lokasi penelitian memiliki kisaran nilai $\mathrm{pH}$, salinitas dan suhu perairan pada lokasi adalah $6-7 ; 34,2-35,75^{\circ} \%$ dan $25-28^{\circ} \mathrm{C}$. Dinyatakan dalam Rustam (2015), bahwa suhu minimum penyu di air berada di atas $21^{\circ} \mathrm{C}$ dan kisaran suhu optimum untuk penyu adalah $27-32^{\circ} \mathrm{C}$. Menurut Hanipa et al. (2017) pH dan salinitas yang baik bagi pemeliharaan penyu adalah pH 6-7; salinitas $34,2-34,75^{\circ} \%$. Suhu air dalam penelitian ini dinyatakan cukup baik bagi kelangsungan hidup tukik Penyu Lekang karena menurut Jackson (1979), jika suhu mengalami peningkatan dapat mempengaruhi laju metabolisme penyu dan mempengaruhi proses pertukaran udara yang terjadi di paru-paru penyu. Air yang memiliki suhu terlalu rendah akan mengurangi aktivitas perilaku dari tukik tersebut dan akan mengurai nafsu makannya. Tingginya tingkat kelangsungan hidup tukik juga didukung oleh kualitas air media pemeliharaan yang relatif konstan dan pemilihan tukik yang sehat dan tidak cacat saat penelitian. Kualitas air dijaga dengan melakukan pergantian air $100 \%$. Maka dari itu pada penelitian ini menggukan pipa air yang akan mengalirkan air kesetiap wadah yang sudah dilubungi disetiap sisinya agar terjadi sirkulasi air yang baik. Pergantian air dilakukan setiap hari yaitu dipagi hari sebelum tukik diberikan pakan agar tukik tidak menjadi stress yang disebabkan kondisi air yang keruh dan bau. Hal ini juga agar kualitas air dalam bak penelitian tetap terjaga sehingga tidak akan mempengaruhi hasil pada penelitian agar tidak menyimpang terhadap teori atau hasil-hasil penelitian yang dilakukan sebelumya.

Hasil pengukuran salinitas cukup stabil selama penelitian. Salinitas termasuk parameter lingkungan yang dapat mempengaruhi kualitas air dalam total konsentrasi osmotik yang dapat mempengaruhi kehidupan organisme yaitu laju pertumbuhan dan kelangsungan hidup biota air. Pada hasil pengukuran $\mathrm{pH}$ air juga cukup netral karena $\mathrm{pH}$ air memiliki kemampuan sebagai penyangga $\mathrm{pH}$. Nilai $\mathrm{pH}$ yang tinggi reaksi akan mengalami pembenukan amoniak yang berbahaya karena bersifat racun bagi penyu. Pernyataan ini juga dipertegas oleh Kushartono et al. (2017), yang menyatakan dengan tingginya nilai $\mathrm{pH}$ dapat menyebabkan tukik dan penyu dewasa yang ada di penangkaran mati karena akan menggangu proses metabolisme dan respirasi pada tukik.

\section{KESIMPULAN}

Berdasarkan hasil penelitian dapat disimpulkan bahwa pemberian pakan dengan komposisi yang berbeda menunjukkan hasil yang berbeda nyata $(p<0,05)$ terhadap pertumbuhan tukik Penyu Lekang (Lepidochelys olivacea). Pemberian pakan Ikan Tongkol 100\% menunjukkan pertumbuhan spesifik berat, panjang karapas dan lebar karapas yang lebih baik dibandingkan dengan perlakuan yang lain. Pakan dengan komposisi Ikan Tongkol 100\% menghasilkan tingkat laju pertumbuhan spesifik berat $1,43 \%$ perhari, panjang karapas $0,62 \%$ perhari dan lebar karapas $0,94 \%$ perhari.

\section{DAFTAR PUSTAKA}

Ario, R., Wibowo, E., Ibnu, P. \& Surya, F. 2016. Pelestarian Habitat Penyu Dari Ancaman Kepunahan Di Turtle Conservation And Education Center (TCEC), Bali. Jurnal Kelautan Tropis, 19(1):60-66.

Dewi. A.A.T., Warpala, I.W.S. \& Mulyadiharja, S. 2018. Variasi Pemberian Jenis Pakan Mnegakibatkan Perbedaan Terhadap Berat Tukik Penyu Lekang (Lepidochelys olivacea) di Tempat Konservasi Penyu Pantai Penimbangan Singaraja. Jurnal Pendidikan Biologi Undiksha, $5(2)$. 
Effendie, I. 1997. Biologi Perikanan. Yayasan Pustaka Utama. $163 \mathrm{hlm}$.

Firdaus, Amri, M. \& Elfirda. 2013. Pengaruh Pemberian Pakan yang Berbeda Terhadap Pertumbuhan Tukik Penyu Hijau (Chelonia mydas). [Karya IImiah]. Jurusan Budidaya FPIK, Universitas Bung Hatta. 12 hal

Hanipa, S., Utami, E.\& Umroh. 2017. Pengaruh Pakan Terhadap Pertumbuhan Tukik Penyu Hijau (Chelonia mydas) di Penangkaran Pantai Tongaci Sungailiat. Jurnal Sumber Daya Perairan, 11(2).

Hardiono, E.B., Rejeki, S.,\& Wibowo, E. 2012. Pengaruh Pemberian Udang Ebi dengan Konsentrasi yang Berbeda terhadap Pertumbuhan Tukik Penyu Lekang (Lepidochelys Olivacea) di Pantai Samas, Bantul. Jurnal Ilmu Kelautan, 1(2):67-72.

IUCN (International Union for Conservation of Nature and Natural Resources). 2011. IUCN Red List of Threatened Spesies. http ://www.iucnredlist.org/

Jackson, D.C. 1979. Respiration, in turtle prespective and research. M. Harles and H. Morlock, (editor). A Wiley Interscience Publication. New York, 165-191pp.

Kushartono, E.W., Ario, R., Pramesti, R., Tiurma, \& Satriadi, A. 2017. Pemberian Pakan Pada Tukik Penyu Hijau (Chelonia mydas Linnaeus,1758) di Konservasi Pulau Bangka. Buletin Oseanografi Marina, 6(2):82-87.

Lazaren, C.C., Karang, I.W.G.A., \& Faiqoh, E. 2018. Perbandingan Laju Pertumbuhan Tukik Penyu Lekang (Lepidochelys olivacea) dengan Pemberian Pakan Ikan Tongkol, Udang Rebon Kering dan Pakan Campuran. Journal of Marine and Aquatic Sciences, 4(1):86-95.

Mansula, J.G., \& Romadhon, A. 2020. Analisis Kesesuain Habitat Peneluran Penyu di Pantai Gianyar, Bali. Juvenil, 1(1):8-18.

Manurung, B., Erianto, \& Rifanjani, S. 2015. Karakteristik Habitat Tempat Bertelur Penyu di Kawasan Taman Wisata Alam Tanjung Belimbing Kecamatan Paloh Kabupaten Sambas. Jurnal Hutan Lestari, 4(2):205-212.

Marzuqi, M., \& Anjusary, D.N. 2013. Kecernaan Nutrien Pakan dengan Kadar Protein dan Lemak Berbeda pada Juvenil Ikan Kerapu Pasir (Epinephelus corallicola). Jurnal IImu dan Teknologi Kelautan Tropis, 5(2):311-32.

Nuansa, F., Rahimi, S.A.E., \& Mellisa, S. 2018. Pemberian Pakan Alami yang Berbeda Terhadap Pertumbuhan Benih Ikan Betutu (Oxyeleotris marmorat). Jurnal IImiah Mahasiswa Kelautan dan Perikanan Unsyiah, 3(2):45-54.

Putra, A.N. 2015. Laju Metabolisme Pada Ikan Nila Berdasaran Pengukuran Tingkat Konsumsi Oksigen. Jurnal Perikanan dan Kelautan. 5(1):1-6.

Rustam. A., \& Prabawa, F.Y. 2015. Kualitas Perairan Di Pantai Punai Dan Pantai Tambak Kabupaten Belitung Timur. Jurnal Segara, 11(1):75-84.

Siegel, Sidney. 1988. Analisis Varians Ranking Satu Arah Kruskal Wallis Statistik Nonparametrik Untuk IImu-IImu Sosial. Gramedia, Jakarta: 230-241.

Sulawesty, F., Chrismadha, T., \& Mulyana, E. 2014. Laju pertumbuhan ikan mas (Cyprinus carpio L) dengan pemberian pakan lemna (Lemna perpusilla TORR.) segar pada kolam sistem aliran tertutup. Jurnal Perairan Darat Tropis di Indonesia, 21(2):117-184.

Suraeda. R.Y., Sunaryo, \& Kushartono, E.W. 2018. Laju Pertumbuhan Spesifik Tukik Penyu Lekang (Lepidochelys olivacea) dengan Pemberian Pakan Buatan Yang Berbeda di Turtle Conservation And Education Center, Bali. Journal of Marine Research, 7(3):185-192.

Wiguna, K.A.W., Suryatini, K.Y.S., Suanda, I.W. \& Wiadnyana, I.G.A.G. 2019. Pengaruh Pemberian Pakan yang Berbeda terhadap Pertumbuhan Tukik Penyu Lekang (Lepidochelys Olivacea) di Turtle Conservation and Education Center Pulau Serangan. Jurnal Emasains, 8(1):94-100 